This item was submitted to Loughborough's Research Repository by the author.

Items in Figshare are protected by copyright, with all rights reserved, unless otherwise indicated.

\title{
The historicity of technological attachments and engagements: the case of Turkish telephony
}

\section{PLEASE CITE THE PUBLISHED VERSION}

http://dx.doi.org/10.1177/0267323116635832

\section{PUBLISHER}

SAGE @ The Author(s)

VERSION

AM (Accepted Manuscript)

\section{PUBLISHER STATEMENT}

This work is made available according to the conditions of the Creative Commons Attribution-NonCommercialNoDerivatives 4.0 International (CC BY-NC-ND 4.0) licence. Full details of this licence are available at: https://creativecommons.org/licenses/by-nc-nd/4.0/

\section{LICENCE}

CC BY-NC-ND 4.0

\section{REPOSITORY RECORD}

Celik, Burce. 2019. "The Historicity of Technological Attachments and Engagements: The Case of Turkish Telephony”. figshare. https://hdl.handle.net/2134/23147. 
European

Journal of

Communication

\section{The historicity of technological attachments and engagements: The case of Turkish telephony}

\begin{tabular}{|r|l|}
\hline Journal: & European Journal of Communication \\
\hline Manuscript ID: & EJC-15-0100 \\
\hline Manuscript Type: & Full Length Article \\
\hline Keywords: & HISTORY, TECHNOLOGY, telephony, symbolic power, Turkey \\
\hline Abstract: & $\begin{array}{l}\text { This article is concerned with the symbolic power of individualized media } \\
\text { technologies in the peripheral contexts of capitalist globality and } \\
\text { modernity. In a critique of studies that have suggested that technologies } \\
\text { as structuring agents of social positions of the users seem to emerge from } \\
\text { the neo-liberalization of the non-West and from the specific use of digital } \\
\text { technologies, I argue that such a positioning has a deeply historical } \\
\text { character. Its historical roots are to be found in the social, political and } \\
\text { cultural regimes of modernity, where it is demanded that agents define and } \\
\text { shape themselves in terms of a capacity to adjust to technological practices } \\
\text { and to employ technologies in order to occupy distinct positions within } \\
\text { social relations. In order to elicit this historicity of symbolic power of } \\
\text { technologies, I focus on the social history of telephony in the post-war } \\
\text { (WWII) era through the 1970s, where the cultural practices of telephony } \\
\text { forcefully deepened social distinctions and functioned to determine the } \\
\text { sense of one's place as well as the place of others, within wider social } \\
\text { relations. }\end{array}$ \\
\hline
\end{tabular}


The historicity of technological attachments and engagements: The case of Turkish telephony

This article is concerned with the symbolic power of individualized media technologies in the peripheral contexts of capitalist globality and modernity. In a critique of studies that have suggested that technologies as structuring agents of social positions of the users seem to emerge from the neo-liberalization of the non-West and from the specific use of digital technologies, I argue that such a positioning has a deeply historical character. Its historical roots are to be found in the social, political and cultural regimes of modernity, where it is demanded that agents define and shape themselves in terms of a capacity to adjust to technological practices and to employ technologies in order to occupy distinct positions within social relations. In order to elicit this historicity of symbolic power of technologies, I focus on the social history of telephony in the postwar (WWII) era through the 1970s, where the cultural practices of telephony forcefully deepened social distinctions and functioned to determine the sense of one's place as well as the place of others, within wider social relations.

\section{Introduction}

In this study, I am interested in exploring, within the Turkish context, the historicity of technological attachments and engagements, where individualized technologies are imagined and practiced as forms of symbolic power. From old telephony to mobile technologies, I argue that technologies have taken the form of symbolic power, in the sense that technologies function as structuring agents of social distinctions and negotiations of dispositions within the social structure. The symbolic power of technologies, in this article, does not simply refer to the representational or display value of individualized technologies that express a modern lifestyle or a refined taste of the user. Instead, it describes a wider meaning structure, where technologies take up the form of empowering resources that constitute, maintain and structure social relations, distinctions and hierarchies (see Bourdieu, 1989). As technologies are embedded in daily practices and imaginations, they also come to function as apparatuses of the user's social, political, ethnic and cultural struggles to alter the existing social reality and hierarchies.

Importantly, the structure of sociotechnical struggles is historically 
contingent and differs across societies, depending on the dynamics of social structure. Much as differences in material, political, social, and economic conditions produce a multiplicity of meanings and performances of technologies across social contexts, the history of relations with former techniques, infrastructures, and tools affects the contingency of technological performances. While infrastructure networks and sociotechnical processes delineate the experiences and structures of feeling of modern urban life, the memory of past experiences with former technologies structures contemporary technological practices and even shapes the form of attachments that individuals and collectives develop to tools, techniques, and technological practices (see Graham and Marvin, 2001; Larkin, 2008). The mania for digital, personal, and mobile technologies in non-Western contexts is related to 'globalization from below' (Alhassan, 2004), to 'recycling modernity' (Sundaram, 2008), and to the production of alternative medial and cognitive practices ranged against authoritarian regimes (Rafael, 2003; Tüfekçi and Wilson, 2012). While these current works generally focus on the contemporary non-West, where the liberalization of the technoscape has led to the emergence of user-generated communicative ecologies, the majority of critical historical research on media and technologies documents the historicity of technological practices in Western contexts (Marvin, 1988). However, the historicity of technologies cannot be limited to the history of the invention, design and production projects of the West. Rather, the history of technologies that inform the contemporary technological world must be extended to include the analysis of how technologies are reshaped and redefined through their very multiplicities, having emerged from the non-West. Moreover, the history of 
modernities in the non-West, as well as in Turkey, has largely been written in terms of projects, discourses, and programs of the modernizing state, colonizing power, and elite classes, which imposed their viewpoints on the public through various social and political apparatuses. The use of technology by the public in these peripheral contexts has largely been considered as an outcome of staterun modernization policies. However, the intriguing issues, including how people have experienced and received the novelties such as technological practices that emerged out of modernization processes in their daily practices and imaginations within these places still need further research. This article aims to contribute to the critical history of technologies, by focusing on the Turkish telephony with a perspective that includes the analysis of state projects as well as the micro-stories of agents, as well as agents' emotional worlds and mental conceptions.

For this reason, I use two domains of resources for my historical research on Turkish telephony: the official professional history (histories that were written and legitimized by state institutions, museums, technical journals and newspapers); and popular memory of the old telephony. I present 'readings' drawn from archival research into representations of the telephone in state documents and the popular press, as well as findings from interviews that were conducted with more than 100 people, who are currently above the 50 years of age, men and women, holding different class positions and political stands. ${ }^{1}$ While the archival research will present how the telephone has been institutionalized as a state service (albeit mostly as a failure), the memory of the users/nonusers and owners/nonowners of telephony in the recent past will shed light on the role of old telephony in social practices and social relations. 
Although popular memory does not offer an 'objective' story of how people have once imagined and engaged with technologies in the previous periods of their lifetimes, it allows us to come closer to an understanding of the play between past and present in personal narratives of technological engagements. The reconstruction or remembrance of the past is not independent of perceptions of the present. Nor is it independent from the dominant perceptions of history, largely shaped by the state and the institutions' narratives of the past (see Spigel, 1995). However, situating a historical project addressing the symbolic power of technologies in Turkey within the dialectical relations between official history and popular memory offers the possibility of understanding how macro-policies and discourses, on the one hand, and memories of people, on the other, feed into, as well as conflict with, each other.

I particularly focus on the social history of telephony in Turkey, primarily because the telephone, as an individualized sound technology, blurs the boundaries of public and private lives, thereby opening up the possibility of a relational analysis of personal and collective relations revolving around the consumption of technology. The telephone was first introduced into Turkey, as a commercial service provided by an internationally owned company, and then, after the foundation of the Republic of Turkey, it was nationalized as an apparatus of the modernizing state, and remained a state service until the mid2000s. Particularly, within the years between the mid 1940s and the 1980s, the state remained unable to link the wider population into telephony despite continuous public demand. As a non-ubiquitous object whose possession and use in private spaces were limited to privileged segments of society, the telephone has become a cultural currency. Ownership by some and non- 
ownership by others forcefully deepened social distinctions, shaping the technological practices and thus coming to function in such a way as to determine the sense of one's place, as well as the place of others, within wider social relations. I also suggest that the history of telephony and its associated resentments, pleasures, and practices informs the collective appetite for technological novelties, such as mobile technologies, which became extremely popular shortly after they were introduced in the mid-1990s as a technology of communication whose use or ownership did not require the approval of state authorities.

\section{The institutionalization of telephony as a "failing" state service}

'There is a new mentality in the country that knows the significance of railways and telecommunications services for the development of a country and a nation' (Cumhuriyet, 1935: 7).

'The telephone is still conceived of as a luxury object in our society. We need to change this. Our nation needs to be enlightened regarding the value of contemporary technologies' (Cumhuriyet, 1935: 3).

The above observations were made by Ali Çetinkaya, who was the Minister of Public Works in the 1930s of Turkey, which was still a very young establishment that was founded in the 1920s, upon the dissolution of the Ottoman Empire. The 'new mentality' of the country that he was proudly announcing implied a necessary break with the Ottoman past, which had become a symbol of a lethargic mentality that had failed to understand and adjust to the changing conditions of nationalism, modernity and capitalism of the $19^{\text {th }}$ and $20^{\text {th }}$ centuries. Although there was no revolutionary theory behind the reforms or the imaginaries of an ideal Turkish country and nation, one thing was certain in the eyes of new rulers: the new republic would be radically 
different from the old empire - a new governmentality regime and a new, modern subjectivity were to be instituted (Mardin, 1994). The official ideology and culture of the new nation would be based on secularism, modernity and Turkish nationalism.

The technological field inherited from the Ottoman Empire was one of the crucial sites for the transformation of both the governmentality regime and of processes of subjectification. From the early republican years, the technological field was nationalized and modernized on the basis of the republican belief in technology as a means of achieving economic, political and cultural unity and progression. The founding belief lay in the assumption that the modernization of the material landscape and the creation of modernity within people's mental conceptions are interrelated. Thus, the more modernized the material landscape became, the more rational, secular and modern people's minds and lifestyles would become.

In line with this broad state project, the country's railway systems and postal services, including the Constantinople Telephone Company, were modernized and nationalized. Previously run by European entrepreneurs, telephone services were expropriated by the state and grouped with postal and telegraph services as part of the institution called the Organization of the Post and Telegraph (Turkish: Posta ve Telgraf Teşkilatı, PTT). The state, the secularist state-elites and the popular media all seem to have agreed on the importance of changing the public's mindset, as well as on the transformations of infrastructures and material landscape: 'We only have a few telephone subscribers in our country, and even these privileged ones are not capable of using the telephone for serious matters; they see it as an object of 
entertainment. Our people have to learn the importance of these communications technologies and use them in appropriate ways" (Resimli Ay, 1925: 9). In addition, the analogy of the necessity, for a well-functioning brain for a healthy body was popularly used to explain the necessity of wellfunctioning telephone systems for a unified and modern body politic (Cumhuriyet, 1940: 2). The telephone in Turkey was not institutionalized as a commodity, then, but first as a modernizing agent of the state with the potential to transform people's life practices and imaginaries. The promise of a domestic telephone was to link the private family home with the modernizing public society and culture.

The first shift in governmental policies with regards to technologies as state agents of material and cultural modernization projects in line with the republican ideals occurred in the aftermath of World War II. In the mid-1940s, Turkey was faced with dramatic economic crises due to the internationalization of productive capital and the division of labor in the global economic landscape. The former single party system and etatist economic policies of the early modernizing state were replaced by a multi-party system and liberal economic policies, which was introduced by the newly elected government. The liberalization of the national economy gave rise to the rapid industrialization, to the decline of social-welfare provisions and to the popular critique of public services such as telephony and telecommunicational infrastructure that does not aim for profitability. The emerging Cold War led to a strategic alignment with the US; the rapid industrialization of agriculture, and the guest worker plans of European countries led to a flow of internal and external migration that has continued in subsequent decades. Americanization of the national culture, rising 
consumerism as well as the increase of import products became topics of critique, particularly in the left-wing press, on the one hand. On the other, the massive transformation in urban landscapes due to the construction of new shantytowns by the migrants and related problems such as the lack of public transportation systems that connect the newly emerging peripheries to the centers of urban areas and the deteriorated infrastructure that always fell short to provide electricity, water and telecommunicational services to the urban peripheries were issues of public critique (Tekeli, 2009). The encounters between urban and migrant identities, which started to become apparent in the 1950s, have created the main axes of the social, political, and cultural tensions between urban and migrant identities (İçduygu, 2005). While the urban identities were privileged and dominant as they were associated with secularist and modern life-styles, the migrants were mostly submerged or subordinated. In this process, certain ethnic and linguistic (Kurds for instance), religious (political Islamists) and rural categories ('peasants' who moved to cities for the search of better means of lives) have been devaluated and marginalized (Kandiyoti, 2004). The use, ownership, skills and knowledge about technologies such as telephony were also integral to the structuration of disparities between urban and migrant identities of cities. Research on telephone books of Istanbul in the 1950s clearly reveals that the practice of telephony was very much limited to a small segment of Istanbul residents that lived in the central and wealthy neighborhoods.

After the 1950s, the disparities between different neighborhoods and life practices gave rise to the even more forceful social, political, and cultural tensions that have continued throughout the history of modern Turkey ever since. From the 1960s to the 1980s, the democratic parliamentary system was 
interrupted by three military coups. While the first one was more left-oriented and was even celebrated by some leftist and secularist groups 'as a move to save the state' (Harris, 2011) (including the technical class working for PTT), the two subsequent military interventions were much more forceful and violent against many political oppositional groups, including the leftists, political Islamists, political Kurds and civil right activists. Throughout the 1960s and 1970s, the Import Substitution Industrialization (ISI) program, which was employed by many other developing nations in the post-World War II era, constituted the basis of economic policies that aimed to decrease the economic, industrial and financial dependence on developed countries. Following the establishment of State Planning Organization (Turkish: Devlet Planlama Teşkilatı) in 1963, the state developed long term plans to replace the flows of import with local industries and products and to repair the deteriorated technological infrastructures. Among the notable developments were the first attempt to manufacture domestic automobiles; to plans to develop the telecommunicational infrastructure; to the establishment of state-run companies like PTT-ARLA (a research and development company that aimed for the innovation and production of national electronic industry that would ideally cut off the dependence on Western technologies, machines and engineering); to the founding of telephone factories like NETAŞ; and to the establishment of the state-run Turkish Radio and Television Corporation (Turkish: Türkiye Radyo ve Televizyon Kurumu, TRT).

Nonetheless, this period between the 1960s and the 1980s was marked more by futile attempts at technological development than by successful outcomes in line with such national developmental plans. For example, the 
attempt to manufacture a national automobile failed, while the telephone-even though it had come to be seen as an essential object of modern urban life by all classes_-still failed to reach full penetration, as millions of people had to wait for years just to get a telephone line. The developmental plans of 1962, 1967, and 1977 reveal that the state was able neither to correctly predict the increase in public demand for telephones nor to provide sufficient supply to potential telephone users. By 1962, there were 192,000 subscribers, but 183,000 were still on the waiting list, while by 1977 the number of subscribers had risen to 851,000 subscribers, but with 1.3 million people still on the waiting list (DPT Development Plans, 1996).

The popular press of the 1960 s and 1970s represented telephony in three primary ways: complaints about the state-run telephone service, news concerning the emerging telephone black market, and depictions of the telephone as a symbol of social status and a modern lifestyle. Numerous newspapers and newspaper headlines voiced complaints about the sad state of telephonic infrastructure and communication, as in the following: "The telephone company still ignores the people's complaints" (Milliyet 1953); “60,000 people still waiting for a telephone line” (Hürriyet 1959); “Turkey the least telephonic nation" (Hürriyet 1960); "All complaining of high fees for telephone connection" (Hürriyet 1972); and "The mute telephone" (Hürriyet 1973). The collective resentment towards state policies that were unable to meet public demand also found resonance in the discourse of technical experts. The authors of technical journals complained of the dysfunctional structure of telephone services, voicing their resentment both toward the public, who did not appreciate their "sacrificial" work, and toward the changing governments, which 
took no responsibility for the failure of their policies.

The disproportion between demand for and supply of telephony also led to the emergence of informal and illegal markets. Between the 1950s and the 1970s, the popular press ran numerous items concerning people selling their telephone subscriptions to others for large amounts of money on an emergent second-hand market and concerning thieves killed by electric shock on telephone poles as they attempted to steal the copper wire to sell it on the black market. This was also a time when there was a great amount of theft and loss of electricity, as well as being the period when the emergence of audio and videocassettes led to a concurrent emergence of film and music piracy in Turkey.

Another interesting manner of representing telephony in the press during this period was to depict actresses, politicians, or bureaucrats speaking on the telephone, even though the accompanying news had nothing to do with telephony. The same was true for advertisements in daily newspapers: illustrations advertising toothpaste, sewing machines, televisions, and batteries were often depicted with people using the telephone. As such, despite the fact that its presence in the visual frame was wholly unrelated to the product being advertised, telephones were being used as visual symbols to suggest to readers that the advertised products could produce a similar affectivity to that of the telephone, such as engaging with all these commodities would provide a kind of social status and allow one to express a modern lifestyle and refined taste. Moreover, downtown photography studios in cities typically had a set where customers could have their photograph taken with a telephone.

The memory of telephony in daily practices and imaginations

In order to explore what the state-run telephony meant for people's lives, 
their daily practices and imaginations, I now turn to the narrated memories of the users, non-users, owners and non-owners of telephony. As mentioned above, the history of migration from rural areas to urban spaces, from the 1950s onwards, has been integral to the history of the structuration of public life and to the fragmentations of social landscape based on class disparities and identity politics. According to the latest quantitative research on cultural values of Turkey, the current social landscape is very much polarized on the basis of identity politics: secularists and Islamists on the one hand, the Turkish nationalists and the ones who define themselves with their Kurdish identity on the other (Esmer, 2012). In order to reflect both the history of migration flows and the political and cultural diversity of contemporary Turkey onto the sample, the research team has visited four big cities and conducted interviews with more than 100 people who are above the 50s years of age: Istanbul, the country's largest city, which was once the Ottoman capital and which has always received the largest inflows of migration, both foreign and domestic; Ankara, the current capital of the Republic of Turkey; Diyarbakır, the city with the largest Kurdish population; and Kayseri, one of the major strongholds of Islamic conservatism in the country. The interviewees have different pasts: some have always lived in urban areas, holding privileged social positions in terms of wealth, education and prestige; some others have migrated from rural Anatolia to big cities, where they had to seek for a job, a place to live in, and the means of social recognition in urban spaces. Some of the latecomers, who have left the conditions of poverty and lack of advanced education in rural areas, have achieved social mobility, through the access to wealth and/or schooling; some others have not. Some define themselves as secularists (mostly the ones who also define themselves 
through their urban pasts), positioning familiarity with technologies as an essential part of secular and urban lifestyle; some others define themselves through their patriotism, religious beliefs or ethnic identities, by recounting their memories of telephony in negotiation with their urban and modern identities. Although some radical secularists might be inclined to think that 'Islamists were never fond of technologies. They considered the telephone as sinful and evil inventions' just as one interviewee has said in Ankara; most of the religious interviewees recounted their experiences with telephony as a practice of negotiation of their religious or traditional and urban/modern identities. For instance, a religious housewife who migrated to Istanbul in the early 60 s and decided to wear black hijab in the 70s has said 'when I first saw [a telephone], I said to myself some gavur ['infidel' a pejorative term used for non-Muslims] had invented it, but God bless him. He did something good for all humanity². Interestingly, the appetite for technological knowledge and use -particularly with regards to the telephone- has been one of the rare practices that aligned different individuals and collectives into a whole society.

Each interview, which has generally lasted around 1 hour, started with a question about the interviewees' earliest memory about telephony, then continued with questions about how they used it, or how they felt if they did not have a chance to use it in their early days. The telephone was first an unfamiliar and curious object, for many interviewees, which obscurely transmitted sound through cables across space. A male retired primary school teacher in Kayseri who is in his mid 60s remembers his first encounter with telephony:

Well, I first saw the telephone in 67. It was in the principal's room where I was a middle-school student. It was forbidden for us to enter his room. But, 
my friends and I wanted to see it, touch it and understand how it worked. The principal was already a respected person in our eyes. But the fact that he owned a telephone made him a very important person in our minds. We were often walking around his door with the hope that we could see how it was used. Before having seen it in the principal's room, I kind of knew what the telephone was. Because in the primary school, our teacher had taught us that there was this machine that carried sound across space. But the machine, he was speaking about, was somewhat modern, abstract to me. Since there was no telephone for him to show us, he was speaking about it hypothetically. He was asking us if our mothers could hear us when we were in the classroom. We were saying, 'nooo'. Then, he was saying, 'but if there was a telephone, you could talk to her with it'. This was not making sense to me at all...

The narration of the first experience with telephony as a curious object that seemed unintelligible is common to many interviewees regardless of where and when they have encountered with this technology. However, the way this interviewee describes his first experiences with this curious object is more illustrative than many other narratives that I collected in this research. The retired primary school teacher, who was schooled in the religiously and culturally conservative Kayseri, uses the term 'modern' and 'abstract' interchangeably to describe the unintelligibility of telephony which he first heard of in the primary school as an abstract machine. The narrated shift from his experience with telephony, as an abstract machine to a concrete one is also a shift from the abstract modern into the recognizable and comprehensible forms of power (the concrete machine adds to the personal authority of the principal). In this respect, the above narration can give us a hint that things and technologies that are claimed to be 'modern' might not have actual value in people's lives except implying some sort of unintelligibility if they do not affect the social positioning of agents in actual life practices. In other words, the modern is an oblique concept to an ordinary citizen; it gains its value as it is 
contested and negotiated in life-practices in terms of its potential to get integrated into power relations, implying distinctive social positions and prestige. A male taxi driver who is in his mid 50s expresses what having a telephone line in one's domestic space implied in his childhood years:

Q: Do you remember the telephone from your years in Kayseri?

A: Only my uncle had it. The ones who had the telephone were mostly seen as rich people. We used to say 'he even has a telephone'. Q: So it was an issue of conversation?

A: Yes, of course. My uncle, for example, was a state officer in Kayseri. A: Was he rich?

A: No, actually. But we used to think that he was an important person. Q: Why?

A: Well, because he had a telephone in his flat. And we came to Kayseri from a little village. His clothes, his family, etc., all reflected his status. He had daughters and they were going to school and actually those girls helped me with my homework. We kind of looked up to them. The whole family I mean. Now we have everything, cell phones, computers, etc. To have these things in our lives were like a dream in those days.

In this account, the uncle who had a telephone was first characterized through the adjective 'rich'; then wealth has changed into a wider conceptualization of power, exemplified through occupation (a job in a state institution), education level (he and his daughters were educated), and residence (he lived in the center of Kayseri). All these qualities of the uncle who had a telephone were implying that 'he was an important person'. As shown above in the previous discussion, the pre-neoliberal period of the 1960s through the 1970 s was a term where the state power was very much involved in the distribution of wealth, education and also technological practices. Thus, in such a landscape, being a subscriber of telephony showed that the owner had an economic capital to pay the high fees of telephonic connections, had a skill and knowledge of the modern technology to conceive its necessity to daily life practices, and had some connections in the state institutions to have a telephone 
subscription while many others were waiting in the lists to get a telephone. The contrast between now and then, in the taxi driver's narrative, describes the transformation of the technoscape where he could not imagine having an access to the means of technologies as a person who came to Kayseri from a small village, lacking money and education into one who enjoys the pleasure of owning and using the contemporary technologies. Much as the conditions of life and technoscape have changed, he also became urbanized throughout those years. In many narratives, the telephone seems to be an object that migrants have first seen after they moved to cities. As such, the lack of memory with telephony in one's life also seemed to explain the deprivation of life-experiences in small villages of Anatolia. A male street vendor in Istanbul who is in his mid 50s and lives in this city for the last 25 years after his migration from a village in Anatolia says:

I don't have any memory with the telephone from my childhood. I even first saw the television from the window of a coffeehouse in İzmir. I couldn't believe how people got inside the screen. I first spoke on a telephone there in İzmir. 'The devil's thing' I thought. That was the only explanation in my mind for a machine to carry sounds. My story is not something that you can know of... My father was putting straw on the floor for my siblings and me to sleep on. We were sleeping together with donkeys. I didn't have a childhood. I didn't even know what money was used for, let alone the telephone. If there were someone inside a house, we would not dare to go in. Until I was 14, I wore nylon shoes. I couldn't even ask my father to buy me a nice pair of shoes. I went to school only for few days in my life. So your questions seem strange to me...

In this account, the interviewee obviously poses a question: how would it be possible for him to have a memory of telephony when he was deprived of all means of good and civilized life? In order to show the absurdity of my research on the meaning of telephony in his own story, he explains the conditions of 
deprivations in reference to his experiences with poverty, lack of education and authoritarian traditionalism that precluded the possibilities of movement, expression, imagination and self-realization. He was, perhaps, also challenging my position as a researcher who possibly approached him with a learned prejudice to ask about his experience as a person who happened to be a streetvendor with a former modern technology in his life. The learned prejudice, he might be protesting through his statements, can well be the one that has been shared by some segments of the urban-elites who considered the lack of knowledge and skills of using a modern technology not as an outcome of a structural problem caused by the uneven distribution of wealth, education and means of modern-urban life practices, but as an outcome of the migrants' inability to adjust their lives and selves to the requirements of modern-urban life. A retired female primary school teacher in Istanbul, who proudly says that she had always lived in Istanbul throughout her life, recounts how the migrants engaged with public telephony:

They did not even know how to use the phone. I remember once I was waiting in line for the telephone booth. There were two men both squeezed in the booth, shouting 'Alo! Aloo!' without even putting the handset to their ears or putting the coin in [...] I was in a hurry, so I said to them, "The person you're calling isn't answering, so let me make my call.' If I had a time, I would have explained to them about how it worked. But I had to rush.

As the knowledge and skills of using the telephone has become a cultural currency, the lack of this currency could also generate a sense of guilt on the parts of the latecomers to the cities. A male restaurant owner who moved to Istanbul when he was in his early 20 s to find a better living for himself recounts his first attempt to make a telephone call in the telephone booth with a remembrance of shame: 
I was trying to find the place to put the coin in, but I was looking at every single corner of the machine and could still not find it. A man behind me was waiting in the queue to make his own call. He couldn't wait anymore, I guess, he just opened the door and showed me where to put it in. I can't forget how I was embarrassed. I was totally blushed. I mean I was a peasant... you know, these mistakes that we make. It was not a mistake, of course, but I felt like that. Then, in time, I have taken out my peasant shirt. I have seen a lot and learned a lot in this life.

Thus, the shift in the way the interviewee has engaged with technologies - the telephone of the early 1970s and the mobile and digital devices of the contemporary era- shows how his sense of place within social space has changed. He was a 'peasant' who was shamefully not able to know how to integrate the modern and urban practices into his own life and yet as he has achieved the means of social mobility - through his success in business and his urbanization - he got rid of his 'peasant' identity. The place of telephony in the negotiated space of rural and urban identities as well as lower class and upper class positions is particularly important, when we think of the ways in which the 'proper' use of technology adds to one's self-perception and self-esteem.

Apart from being the historical ground for the negotiations of class positions and urban-modern identities, the telephone has also generated a space where the traditional (brotherhood, solidarity, communal life) and the modern (individualism, privacy of domestic spaces) were negotiated. The privileged who were in possession of a telephone needed to be responsible citizens and good neighbors - regardless of whether they willingly or unwillingly, gladly or reluctantly, shared their telephone with others. Guests were also expected to be respectful and discreet in terms of keeping their conversations short, quiet and formal. A social historian resident in Diyarbakır describes the practice of sharing, and the power of the sharer within the 
community, as follows:

A house with a telephone functioned like a public telephone booth. If someone had a telephone in a neighborhood, then it was as if the whole neighborhood could use it. My uncle had a telephone in his house. His wife was like an operator. When a call came to one of the residents in the neighborhood, she would go to the window and shout the name of the person being called: 'Ayșe... Ayşe... You have a call from Istanbul!' But, if she got angry with one of the neighbors for some reason, she wouldn't tell them when they received a call.

The ritualized form of sharing telephony did not, however, necessarily lead to the transgression of existing social boundaries by creating new possibilities of solidarity between incommensurables. The memories of sharing telephony with others do not suggest a practice where the already segregated political, social and religious groups encounter with each other through the collective use of a domestic telephone. Rather the practice of sharing telephony reinforced the social ties between the ones who already share a common history, religion or ethnic identity (Sunni Muslims, migrants from the same village or neighboring villages, the ones who shared the political and social stances and also amongst women and men separately) and contributed to the reproductions of borders and segregations between polarized groups. The already existing social borders came to be reinforced through the host's decisions about whom to share the cultural currency with. For instance, an Alevi (a religious minority group of Turkey) family who lived in Ankara without a telephone recounted that 'all the residents of the building used one person's telephone, but we never approached them to ask, nor did they offer any help with the telephone. They shared it among themselves.'

\section{The three conclusive remarks}

In this article, I have tried to describe those sociotechnical, economic, 
and cultural contexts of local modernity in which technologies, particularly telephony, have been embedded in the negotiations of social positions and have reinforced social distinctions in the recent history of modern Turkey. My aim has been to show that there is a cumulative history behind the passionate use of 'new' technologies in countries such as Turkey; that is, in countries where the historical dynamics of multiple modernities mediate how people engage with, perceive, and use technologies. The findings of the research can be summarized with three conclusive remarks:

1. The telephone in Turkey was primarily institutionalized as an instrument of modernizing and secularizing state power. When it was in high demand but in low supply, from the early 1950s through the 1970s, it has shaped the technological belief and practices of users and non-users in terms of acknowledging the role of telephony as the preserve of a privileged minority. While the official history of telephony whose contours were drawn by the state policies and discourses show that the state power attempted and yet failed to bring forth the widely shared telephonic connections as a means to unify and modernize the country and the nation, the popular memories have shown that the failing modern technology triggered more and more resentment, anger, frustration and also attachment to technologies as powerful practices for the social struggle of users. The memories about the telephone in this period have also explored that the telephone was more of a technology of social power, demarcating distinctions between individuals and collectives, rather than a technology of modernity that does not mean much unless it is translated into power relations. In this respect, I believe that the findings drawn from the memories of Turkish telephone users and non-users can inform the future 
studies to understand the constant play between the modern and the forms of power in non-Western contexts: the celebrations of modernity and the modern objects in the state discourses or journalistic representations necessarily feed into the forms of power that technologies attain in social practices of daily life. However, the actual symbolic value of technologies is shaped through daily practices and imaginations of agents where they negotiate the instrumentality of modern technologies for their endeavor to negotiate their social positions within social space. In actual use of telephony, the abstract modernity of the object sinks away and dissolves into comprehensible forms of power that increases the personal authority of the owner or user of the telephone. The combination of the telephone owner and her telephone modifies both elements to some degree: the telephone becomes an object of social power whose abstractness and unfamiliarity is modified by the ownership of those who hold privileged social positions, and the telephone owner becomes a person whose cultural, economic and social power is recognized due to her knowledge and skills of appropriating and using the modern. In this regard, a technology like telephony as a modern object is merely an abstract object; it becomes what it is in the daily practices, rituals and imaginations of its users/nonusers.

2. The Turkish experience with telephony demonstrates how the history of the mode of engagement with technologies can become a ground for agents to negotiate their past and the present subjecthoods. The accumulation of knowledge, skills and use of technologies throughout one's life story could easily be narrated as a change from an incompetent or deprived self into a skilled and proud subject positions. In a similar manner, the structural transformation of the state-run technological field into the neo-liberal, 
autonomous technological field that enables the use of technology without the approval of state authorities could be narrated as a form of progress in the domain of agency of the user. In this respect, it is important to note that the subjective (the migrant who becomes urbanized and gains the skills and knowledge of technology use) and objective conditions (the conditions of migration and/or the state policies regarding the technological field) are deeply interrelated in social practices. In social space, agents develop their technological practices in relation to their social positions (such as the social class they belong to and their histories of migration). Accordingly, the changes and shifts within the technological practices affect one's sense of place and are reflected on how they conceive their own changing status in social space. I believe, Pierre Bourdieu's concept of habitus is very useful to understand the technological practices and imaginations of users mainly because habitus is a concept that allows us to recognize how objective conditions are internalized by the agent and affect her actions, thoughts and feelings in relation both to her own position and others'. Moreover, the concept of habitus is a historical set of practices where the knowledge and memory of the past is integrated into current actions and imaginations of agents. Even though, Bourdieu never directly speaks of technological practices in his research, it is possible to consider technologies as 'subsets of habitus' (Sterne, 2003) which do not only reproduce social hierarchies but also deepen them and make them much more visible, felt, and experienced by agents functioning in social spaces. As I have attempted to show, the social practice of the problematic state telephony system divided the social landscape more than it connected it, reinforced the limits of social boundaries more than it weakened them, and fed the means of 
social distinctions and hierarchies more than it created a form of unity and commonality. It is impossible to dissociate the collective appetite and attachment for the contemporary technologies from the history of technological practices, the collective memories of former techniques and the memories of frustrations and resentments, especially on the part of those who have been historically excluded from the technological experiences and subjected to forms of symbolic violence based on their assumed incapacity to use, know and appropriate technologies into their lives.

3. The neo-liberalization in the non-Western contexts in the post-1980s has led to the emergence of possibilities of liberty and freedom in terms of expressions of self-hood, body and alternative political and cultural identities in public spaces. The emergence of veiled students claiming their right to a higher education, the increasing visibility of singers, actors, and celebrities from the outskirts of cities, and the ever widening possibilities consumption were considered by some scholars in Turkey to be even proofs of the emergence of civil society (Göle, 1994). However, as Cornellius Castoriadis (2003) has pointed out, the destructuration of previous regimes of authoritarianism and exploitation, in the neo-liberal era of the 1980s, did not necessarily lead to the emergence of autonomous societies and individuals. Instead, as we can observe in Turkey, the neo-liberalization gave rise to the increased forms of commodification where possibilities of liberty, freedom, equality, selfrealization and even happiness are searched within commodified areas, including the commodified technoscape. On a daily basis and in the sheer banality of everyday life practices, users perceive, approach, and engage with differing technologies in order to assert their identities, realize their own self- 
curating projects, and increase their visibility in social spaces both online and offline. The national mania for the possession and use of personalized technologies continues to forge the means of illusionary or otherwise social recognition and of commodified forms of the purchasable pleasures of selfmaking. However, more research is needed on the ways in which technologies go beyond their merely instrumental functions and mundane meanings within and across different social contexts. In understanding what is wrapped in contemporary technologies that come to function as cultural and social currencies, particularly in the less privileged spaces of globality, such research needs to seek out not only the pleasures of current practices, but also the ghosts of history and past experience and the collective memories of collective wounds.

\footnotetext{
1 This research on the history of Turkish telephony was funded by XXXXXX and completed in 2013. While I led the research project, XXXXX contributed to the project by conducting some of the interviews and archival research.

References

The 7th State Development Plans. (1996) http:///ekutup.dpt.gov.tr/plan/vii/plan7.pdf.

Alhassan, Amir (2004) Development communication policy and economic fundamentalism in Ghana.

Bourdieu, Pierre (1989) 'Social space and symbolic power' Sociological Theory 7(1): 14-25.

Castoriadis, Cornelius (2003) The rising tide of insignificance.

http://www.notbored.org/RTI.pdf.

Crary, Jonathan (1999) Suspensions of perception: Attention, spectacle, and modern culture. Cambridge, MA: MIT Press.

Cumhuriyet (1935) Ali Çetinkaya Müjdeliyor [Ali Çetinkaya gives the good news]. 25 November. Cumhuriyet (1940) İnme [Stroke]. 28 December.
} 
Cumhuriyet (1935) Posta ve Telgraf Bütçesi Müzakere Edilirken [While the budget for the post and telegraph is debated].14 April.

Esmer, Yılmaz (2012) Türkiye Kültürel Değerler Araşttrması. İstanbul: Bahcesehir Universitesi.

Göle, Nilüfer (1994) 'Towards an autonomization of politics and civil society in Turkey'. In Politics in the Third Turkish Republic. Westview Press, Boulder.

Graham, Stephen and Simon Marvin (2001). Splintering urbanism: Networked infrastructures, technological mobilities and the urban condition. London: Routledge.

Harris, George (2011). 'Military coups and Turkish democracy, 1960-1980'. Turkish Studies 12: 2, 203-11.

Hürriyet (1959) 60 Bin Kişi Hala Telefon Kuyruklarında Bekliyor [60,000 people still waiting for a telephone line]. 22 May.

Hürriyet (1960) Türkler Telefonu En Az Kullanan Millet [Turkey the least telephonic nation]. 28 May.

Hürriyet (1972) Herkes Telefonun Yüksek Ücretlerinden Şikayetçi [Everyone complaining of high fees for telephone connection]. 3 April.

İçduygu, Ahmet (2005) 'Migration, remittances and their impact on economic development in Turkey' in Ahmet İçduygu (ed.) Migration, Remittances and Development. Paris: OECD.

Kandiyoti, Deniz (1991) 'Identity and its discontents: women and the nation.'Millenium: Journal of International Studies 20: 3, 429-43.

Larkin, Brian (2008) Signal and noise: Media, infrastructure, and urban culture in Nigeria. Durham: Duke University Press.

Mardin, Şerif (1994) 'Cultural change and the intellectual: A study of the effects of secularization in modern Turkey,' pp. 153-89 in Şerif Mardin (ed.) Cultural Transition in the Middle East. Leiden: Social Economic and Political Studies of the Middle East.

Marvin, Carolyn (1988) When old technologies were new: Thinking about electric communication in the late nineteenth century. New York: Oxford University Press.

Milliyet (1953) Konuşamayan Telefon [The mute telephone]. 10 September.

Milliyet (1986) Muasır Medeniyetler Seviyesine Telefonla Erişiyoruz [We're catching up with contemporary civilizations through telephone systems]. 24 April.

Rafael, Vicente (2003) 'The cell phone and the crowd: Messianic politics in the contemporary Philippines' Public Culture. doi:10.1215/08992363-15-3-399

Spiegel, Lynn (1995) 'From the dark ages to the golden age: Women's memories and television reruns'. Screen. 36: 1, 16-33.

Sterne, J. (2003). Bourdieu, technique and technology. Cultural Studies. doi:10.1080/0950238032000083863a

Sundaram, R. (2008). Recycling modernity: Priate electronic cultures in India. Third Text 13: 47, 59-65. http://dx.doi.org/10.1080/09528829908576796 
Tufekci, Zeynep and Christopher Wilson (2012) Social Media and the Decision to Participate in Political Protest: Observations from Tahrir Square. Journal of Communication. doi:10.1111/j.1460-2466.2012.01629.x 